\title{
DEVELOPING AND EVALUATING SOLAR ENERGY TECHNIQUES FOR TEA DRYING
}

\author{
S. KONESWARAMOORTHY, M.T. ZIYAD MOHAMED* and G. GALAHITIYAWA \\ Tea Research Institute of Sri Lanka, Talawakelle.
}

(Received: 26 June 2001 ; accepted: 11 September 2003)

\begin{abstract}
A feasibility study was undertaken to supplement solar energy for tea drying. A solar thermal field consisting of 200 flat plate solar collectors, coupled to a furnace cum heat exchanger was commissioned to pre-heat the air used for tea drying. The performance of the system was monitored and the preliminary results indicate a saving of $25-34 \%$ on fuel used for tea drying. This system could also be used for re-firing of graded teas, without an auxiliary source.
\end{abstract}

Key words: Flat plate collectors, solar energy, tea drying,

\section{INTRODUCTION}

Solar is a promising renewable energy source. Solar drying is used extensively in drying agricultural produce in several European countries and in some Asian countries. In Indonesia, it was reported that the firewood consumption was brought down from $1.0-1.5 \mathrm{~kg} \mathrm{~kg}^{-1} \mathrm{dry}$ rubber to about $0.3 \mathrm{~kg} \mathrm{~kg}^{-1} \mathrm{dry}$ rubber using flat plate solar air heater connected to the drying chamber. ${ }^{1}$ Roof integrated solar fields have been tested for black tea processing in India. With a solar hot air system at Golden Hills tea factory in Coonoor, Tamil Nadu, there was a saving of $34 \%$ on fuel usage. ${ }^{2}$

The unit operations in tea processing are withering, rolling, roll breaking, fermenting, drying and grading. Thermal energy is used for removal of moisture in the unit operations of withering and drying in black tea processing. Firewood and oil are the two common sources of fuel in Sri Lanka. Tea industry in Sri Lanka, accounts for $33 \%$ of the industrial firewood consumption and it is also the second largest consumer of oil. ${ }^{3}$ Clean odourless hot air is required during withering and drying stages of tea processing. Heat is generated by combustion of fuel and transferred to processing air through heat exchangers.

\section{Thermal energy demand for tea processing}

The drying potential of air depends on volume of air, the relative humidity of the air supplied and dry bulb temperature. Specific thermal energy needed for withering is $5.6 \mathrm{MJ} \mathrm{kg}^{-1}$ made tea according to energy audits carried out in the past. ${ }^{4}$ A minimum of $2.5^{\circ} \mathrm{C}$ difference between dry bulb and wet bulb temperature is needed for withering. If the difference is below this limit, rate of withering will be too slow. ${ }^{5}$ Therefore, temperatures should be adjusted to achieve the difference. However, when

\footnotetext{
" Corresponding author
} 
hot air is used to achieve the difference with increasing dry bulb temperature, the quality of made tea degrades.

Drying needs higher thermal energy compared to withering. There are three types of driers commonly used for tea drying, viz conventional endless chain pressure (ECP) type drier, fluidised bed drier (FBD) and combination drier which works on a combination of ECP and FBD principles. ECP drier is operated with an inlet temperature of $95-100^{\circ} \mathrm{C}$ and an exhaust temperature of $50-55^{\circ} \mathrm{C}$. The average specific thermal energy needed for drying is $11.0 \mathrm{MJ} \mathrm{kg}^{-1}$ made tea. ${ }^{4}$ Therefore, there is a potential to supplement part of the above energy requirement with solar energy

\section{Solar Collectors}

Solar collector is a device for converting solar radiant energy to heat in a fluid. There are two types of solar collectors, namely the flat plate collectors and the concentrating collectors. In the flat plate collector, the area absorbing solar radiation is approximately equal to the area exposed to the radiation. A concentrating collector is one, which usually contains reflectors or employs other optical means to concentrate the energy falling on the aperture on to a heat exchanger of smaller area than aperture. Cost of a concentrating collector field will be very much higher compared to that of a flat plate collector solar field. Usually, concentrating type collectors are coupled with systems operating on higher temperature with low airflow. Since the airflow required for tea dryers and withering troughs is of the order of $100 \mathrm{~m}^{3} \mathrm{~min}$ ${ }^{1}$, flat plate collectors are economically more attractive than concentrating collectors.

It is very important to maintain a steady inlet temperature in tea dryers, to ensure quality of tea produced, as several chemical changes also occur during drying. As such, an auxiliary system coupled with solar field is essential to achieve such steady temperature, when there are cloud covers.

During the grading operation, tea absorbs moisture from the air in the grading room. If the moisture content of the graded tea at the time of packing is higher than the accepted level (5\% on wet basis), graded tea should be re-fired before packing. As the temperature needed for re-firing is $55-60^{\circ} \mathrm{C}$, the flat plate collector solar field could be used without an auxiliary system for this purpose.

In this paper, the performance of the solar flat plate collectors for pre-heating the air used for tea drying is discussed.

\section{METHODS AND MATERIALS}

Fabrication and Testing: Collectors were fabricated and tested to arrive at the best design, taking into consideration the following: 

a) type of frame
b) cost effective material for absorber plate
c) number of glazing
d) gap between the absorber plate and glazing
e) air flow path inside the collector

Initially, it was decided to fabricate the frame out of wood and use double glazing with cellophane as the material for inner glazing and corrugated aluminium as the absorber plate. Through preliminary observations, it was felt that, galvanized-iron (G.I) sheets could be equally effective compared to aluminium sheet as the absorber plate. Hence, collectors with nine different designs were fabricated and tested.

\section{Materials used for fabrication:}
a) Frame
: Wood or Zinc alum
b) Glazing
: $3 \mathrm{~mm}$ tempered low iron glass or/and cellophane sheet
c) Absorber plate : corrugated aluminium or galvanised iron roofing sheet, coated with black matt paint
d) Insulation $\cdot$ : rubberized coir

\section{Table 1: Design details of all nine collectors}

\begin{tabular}{|c|c|c|c|c|c|c|}
\hline$\overline{\text { No }}$ & $\begin{array}{c}\text { Weight } \\
(\mathrm{kg})\end{array}$ & Frame & Glazing & $\operatorname{Gap}^{*}(\mathrm{~cm})$ & Airflow & $\begin{array}{c}\text { Absorber } \\
\text { plate }\end{array}$ \\
\hline 1 & 56 & Wood & Single: glass & 5 & Rear & $\mathrm{Al}$ \\
\hline 2 & 56 & Wood & $\begin{array}{c}\text { Double :glass } \\
\text { cellophane }\end{array}$ & 5 & Rear & $\mathrm{Al}$ \\
\hline 3 & 56 & Wood & Single: glass & 2.5 & Rear & $\mathrm{Al}$ \\
\hline 4 & 30 & Zinc-alum & Single: glass & 5 & Rear & $\mathrm{Al}$ \\
\hline 5 & 30 & Zinc-alum & Single: glass & 5 & $\begin{array}{l}\text { Rear \& } \\
\text { above }\end{array}$ & $\mathrm{Al}$ \\
\hline 6 & 33 & Zinc-alum & Single: glass & 5 & Rear & G.I \\
\hline 7 & 33 & Zinc-alum & Single: glass & 5 & Above & G.I \\
\hline 8 & 44 & Zinc-alum & Double: glass & 5 & Rear & $\mathrm{Al}$ \\
\hline 9 & 44 & Zinc-alum & Double: glass & 5 & Rear & G.I \\
\hline
\end{tabular}

* Gap - gap between the top glazing and absorber plate

* G.I - Galvanized iron, Al - Aluminium 
Design details and weights of all nine collectors are given in Table 1. All the tests were carried out at St. Joachim tea factory, Ratnapura managed by the Tea Research Institute of Sri Lanka.

At the initial stage of testing (tests I to V), collectors were tested in pairs. Airflow was adjusted to $60 \mathrm{~kg} \mathrm{~h}^{-1} \mathrm{~m}^{-2}\left(24 \mathrm{ls}^{-1}\right)$, during the tests. Airflow rate was measured using two calibrated bends. Outlet temperatures of the air from the collectors were recorded hourly from 9.00 a.m. to 6.00 p.m. and average outlet temperatures were recorded.

Cellophane was tested as inner glazing in collector No 2, but it was damaged due to high temperature under stagnation condition. As such this design was rejected. Following tests were carried out to compare the performance of the collectors 1 to 7 .

Test I : Comparing the performance of collectors 1 and 3 having different gaps between glazing and absorber plate.

Test II : Comparing the performance of collectors 1 and 4 having wooden and zinc alum frame.

Test III: Comparing the performance of collectors 4 (rear duct air flow) and 5 (rear and above duct. air flow).

Test IV: Comparing the performance of collectors 4 and 6 having Aluminium and G.I absorber plate.

Test V : Comparing the performance of collectors 6 and 7 having rear duct air flow and above duct airflow.

Based on results from Test I, it was concluded that a gap of $5 \mathrm{~cm}$ between the absorber plate and the glazing is comparable to that of $2.5 \mathrm{~cm}$.

Based on results from Test II it was concluded that the performance of the collector with Zinc Alum frame is comparable to that with wooden frame. However taking into consideration the weight, cost, durability etc, the Zinc Alum frame was selected.

Based on results from Test III \& V collectors $5 \& 7$ were rejected as their performances were found to be poor compared to collectors $4 \& 6$.

Based on results from Test IV it was concluded that the performance of the collector 4 is comparable to that of collector 6 . However the cost of fabricating collector 4 is less compared to that of fabricating collector 4 and hence collector 6 was selected for further testing.

To finalize the design, it was decided to compare the efficiencies of collectors $6 \& 9$ and also heat loss coefficients of these two along with collectors $4 \& 8$. 
Test VI : Comparing the performance of collectors 6 and 9 having single and dou ble glass glazing respectively.

Tests were carried out between 11.15 a.m. to 12.45 p.m. with average solar radiation greater than $630 \mathrm{~W} \mathrm{~m}^{-2}$ and was "quasi steady" to compare the efficiency of both collectors. Solar intensity (measured on the collector plane), ambient temperature and temperature of outlet air from each collector were recorded every 15 minutes from 11.15 a.m. to 12.45 p.m. ${ }^{6}$ Specific airflow through both collectors was $60 \mathrm{~kg} \mathrm{~h}^{-1} \mathrm{~m}^{-2}\left(24 \mathrm{l} \mathrm{s}^{-1}\right)$.

Efficiency of both collectors was calculated using equation 1.

$\eta=\mathrm{mC}_{\mathrm{p}}\left(\mathrm{T}_{\mathrm{f}, \mathrm{o}}-\mathrm{T}_{\mathrm{f}, \mathrm{i}}\right) / \mathrm{IA}$

Where,

$\eta \quad$ - Collector efficiency

A - aperture area of the collector $\left(\mathrm{m}^{2}\right)$

$C_{p}$ - specific heat of heat transfer fluid $\left(\mathrm{J} \mathrm{kg}^{-1} \mathrm{~s}^{-1}\right)$

I - solar intensity on the sloping collector $\left(\mathrm{W} \mathrm{m}^{-1}\right)$

$\mathrm{m}$ - mass flow rate of the fluid through the collector $\left(\mathrm{kg} \mathrm{s}^{-1}\right)$

$\mathrm{T}_{\mathrm{f}, \mathrm{i}}$ - temperature of the heat transfer fluid entering the collector $\left({ }^{\circ} \mathrm{C}\right)$

$\mathrm{T}_{\mathrm{f}, \mathrm{o}}$ - temperature of the heat transfer fluid at the collector outlet $\left({ }^{\circ} \mathrm{C}\right)$

Efficiency of collectors 6 and 9 were $54.4 \%$ and 56.3\% respectively. Aperture area of the collector considered for the calculation $=1.84 \mathrm{~m} \mathrm{x} 0.93 \mathrm{~m}=1.7 \mathrm{~m}^{2}$

Test VII : Comparison of over all heat loss coefficients

Collectors 4, 6, 8 and 9 were exposed to stagnation condition. Absorber plate temperature, solar intensity and ambient temperature were measured at noon. Tests were repeated for three days. Overall heat loss coefficients were calculated using equation 2 and results are presented in Tables 4 to 7.

Under stagnation condition, all the solar energy absorbed by absorber plate is lost to surrounding through collector components. Heat balance equation for a unit area of absorber plate is as follows:

$\mathrm{I}(\tau \alpha)_{\mathrm{e}}=\mathrm{U}_{\mathrm{L}} \times\left(\mathrm{T}_{\mathrm{ABS}}-\mathrm{T}_{\mathrm{AMB}}\right)$

Where,

$(\tau \alpha)_{e}$ - effective transmittance - absorptance product of the collector

I - solar energy received on the upper surface of the sloping collector (W $\left.\mathrm{m}^{-2}\right)$ 
$\mathrm{T}_{\mathrm{AMB}}$ - ambient temperature $\left({ }^{\circ} \mathrm{C}\right)$

$\mathrm{T}_{\mathrm{AB}} \mathrm{S}$ - temperature of absorber plate $\left({ }^{\circ} \mathrm{C}\right)$

$\mathrm{U}_{\mathrm{L}} \quad$ - overall heat loss co-efficient $\left(\mathrm{W} \mathrm{m}^{-2}{ }^{\circ} \mathrm{C}^{-1}\right)$

\section{RESULTS AND DISCUSSION}

Cellophane was tested as inner glazing for collector No 2. During stagnation condition, cellophane was damaged due to high temperature. Therefore, it was concluded that the use of cellophane as inner glazing is not possible.

Table 2 : Average outlet temperature of air.

\begin{tabular}{ccc}
\hline \multirow{2}{*}{ Test I } & Collector 1 & $\begin{array}{c}\text { Average outlet } \\
\text { Temperature }\left({ }^{\circ} \mathrm{C}\right)\end{array}$ \\
& Collector 3 & 49.5 \\
Test II & Collector 1 & 48.9 \\
& Collector 4 & 49.1 \\
Test III & Collector 4 & 50.2 \\
& Collector 5 & 55.6 \\
Test IV & Collector 4 & 53.5 \\
& Collector 6 & 51.0 \\
Test V & Collector 6 & 50.0 \\
& Collector 7 & 53.0 \\
\hline
\end{tabular}

Table 3: Performance of collectors 6 and 9.

\begin{tabular}{ccccc}
\hline Time (hrs) & $\begin{array}{c}\text { Intensity } \\
\left(\mathrm{Wm}^{-2}\right)\end{array}$ & $\mathrm{T}_{\text {AMB }}\left({ }^{\circ} \mathrm{C}\right)$ & $\begin{array}{c}\mathrm{T}_{\text {out }}^{6} \\
\left({ }^{\circ} \mathrm{C}\right)\end{array}$ & $\begin{array}{c}\mathrm{T}^{9}{ }_{\text {out }} \\
\left({ }^{\circ} \mathrm{C}\right)\end{array}$ \\
\hline 11.15 & 1000 & 33 & 62 & 62 \\
11.30 & 1000 & 33 & 65 & 65 \\
11.45 & 1012.5 & 33 & 67 & 67 \\
12.00 & 1012.5 & 34 & 68 & 69 \\
12.15 & 1025 & 34 & 70 & 72 \\
12.30 & 1025 & 34 & 70 & 73 \\
12.45 & 1087.5 & 35 & 74 & 77 \\
Average & 1023.2 & 33.7 & 68 & 69.2 \\
\hline
\end{tabular}


Table 4 : Overall heat loss coefficient of collector 4.

\begin{tabular}{lccc}
\hline $\mathrm{I}\left(\mathrm{Wm}^{-2}\right)$ & $\mathrm{T}_{\mathrm{ABS}}\left({ }^{\circ} \mathrm{C}\right)$ & $\mathrm{U}_{\mathrm{L}}\left(\mathrm{Wm}^{-2} \mathrm{C}^{-1}\right)$ & $\mathrm{T}_{\mathrm{AMB}}\left({ }^{\circ} \mathrm{C}\right)$ \\
\hline 1077 & 118 & 11.5 & 35 \\
907.5 & 110 & 10.8 & 35 \\
552.5 & 76 & 11.7 & 32 \\
Average & & 11.3 & \\
\hline
\end{tabular}

Table 5 : Overall heat loss coefficient of collector 6.

\begin{tabular}{lccc}
\hline $\mathrm{I}\left(\mathrm{Wm}^{-2}\right)$ & $\mathrm{T}_{\mathrm{ABS}}\left({ }^{\circ} \mathrm{C}\right)$ & $\mathrm{U}_{\mathrm{L}}\left(\mathrm{Wm}^{\left.-2^{\circ} \mathrm{C}^{-1}\right)}\right.$ & $\mathrm{T}_{\mathrm{AMB}}\left({ }^{\circ} \mathrm{C}\right)$ \\
\hline 1077 & 127 & 8.5 & 35 \\
907.5 & 120 & 7.8 & 35 \\
552.5 & 84 & 7.8 & 32 \\
Average & & 8.1 & \\
\hline
\end{tabular}

Table 6 : Overall heat loss coefficient of collector 8.

\begin{tabular}{lccc}
\hline $\mathrm{I}\left(\mathrm{Wm}^{-2}\right)$ & $\mathrm{T}_{\mathrm{ABS}}\left({ }^{\circ} \mathrm{C}\right)$ & $\mathrm{U}_{\mathrm{L}}\left(\mathrm{Wm}^{\left.-2^{\circ} \mathrm{C}^{-1}\right)}\right.$ & $\mathrm{T}_{\mathrm{AMB}}\left({ }^{\circ} \mathrm{C}\right)$ \\
\hline 1077 & 105 & 13.6 & 35 \\
907.5 & 100 & 12.4 & 35 \\
552.5 & 70 & 12.9 & 32 \\
Average & & 12.9 & \\
\hline
\end{tabular}

Table 7 : Overall heat loss coefficient of collector 9.

\begin{tabular}{lccc}
\hline $\mathrm{I}\left(\mathrm{Wm}^{-2}\right)$ & $\mathrm{T}_{\mathrm{ABS}}\left({ }^{\circ} \mathrm{C}\right)$ & $\mathrm{U}_{\mathrm{L}}\left(\mathrm{Wm}^{\left.-2^{\circ} \mathrm{C}^{-1}\right)}\right.$ & $\mathrm{T}_{\mathrm{AMB}}\left({ }^{\circ} \mathrm{C}\right)$ \\
\hline 1077 & 105 & 11.2 & 35 \\
907.5 & 100 & 10.1 & 35 \\
552.5 & 72 & 10.6 & 32 \\
Average & & 10.6 & \\
\hline
\end{tabular}

Collector number 6 was selected as the best for this project, considering efficiency, overall heat loss coefficient, cost and weight. Cost of fabricating one collector with designs 6 and 9 is Rs. 3,900/= and 6,400/= respectively. Even though 
efficiency of collector 9 is slightly higher than that of 6 , due to the lower cost and weight, collector 6 was selected.

Details of the collector selected are as follows:

a) Zinc alum frame

b) Single glass glazing

c) Corrugated G.I roofing sheet as the absorber plate

d) Rear duct airflow

Figure 1 gives the three-dimensional view of one collector with dimensions. A solar field with 200 collectors and necessary ducting was constructed (Figures $2 \& 3$ ). All collectors were connected in parallel. Collectors were supported with pre-cast concrete columns and beams. A 7.5 H.P $(5.6 \mathrm{~kW})$ centrifugal fan was used to couple the solar field with air heater. The air heater, tubeless type is coupled to a three stage Endless Chain Pressure (ECP) drier with 4 feet $(1.22 \mathrm{~m})$ width giving an average output of $110 \mathrm{~kg}$ made tea/hour for leaf with $55 \%$ moisture. System was commissioned and the performance monitored for about 6 months and some data are presented in Table 8. Auxiliary heat supply was from diesel-fired burner. The intensity of solar radiation during the tests varied between $285 \mathrm{~W} \mathrm{~m}^{-2}$ (with cloud cover) and $1206 \mathrm{~W} \mathrm{~m}^{-2}$ between 8 a.m. -4 p.m. (Figure 4). The weekly data collected on sunshine hours, during a year in Ratnapura is presented in Figure 5.

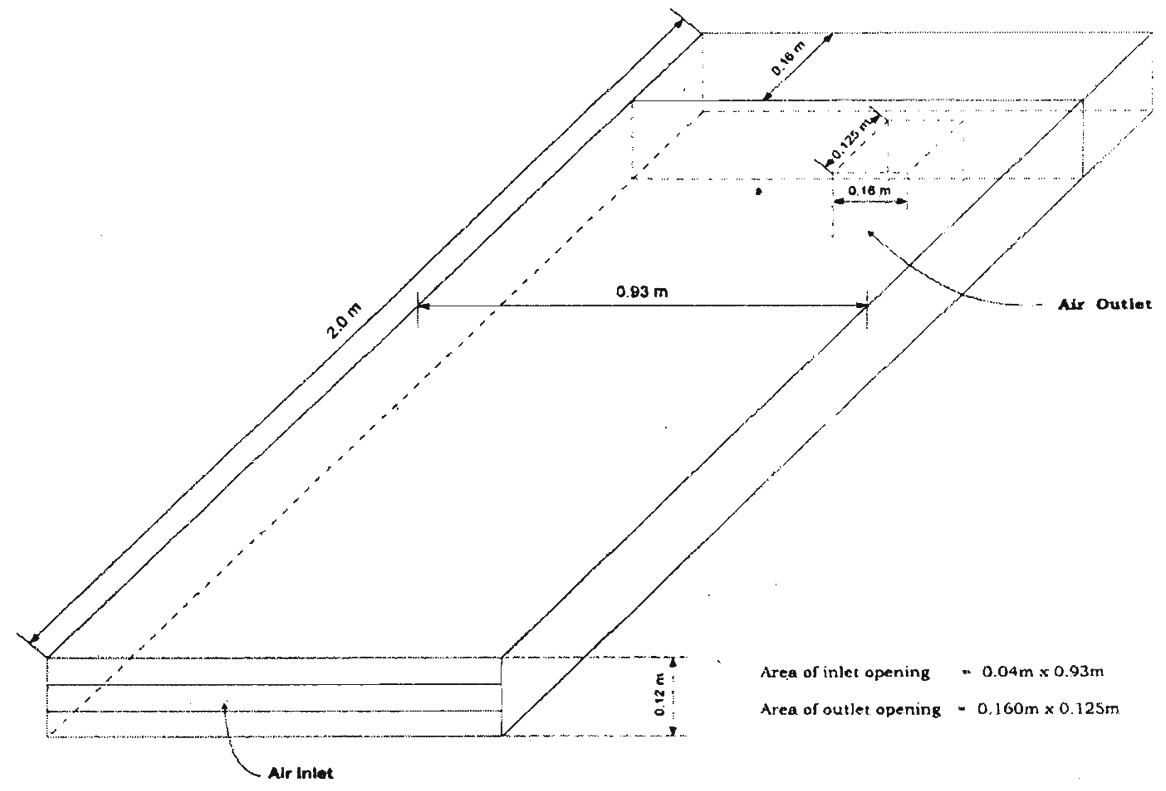

Figure 1: Dimensions of a single solar collector. 


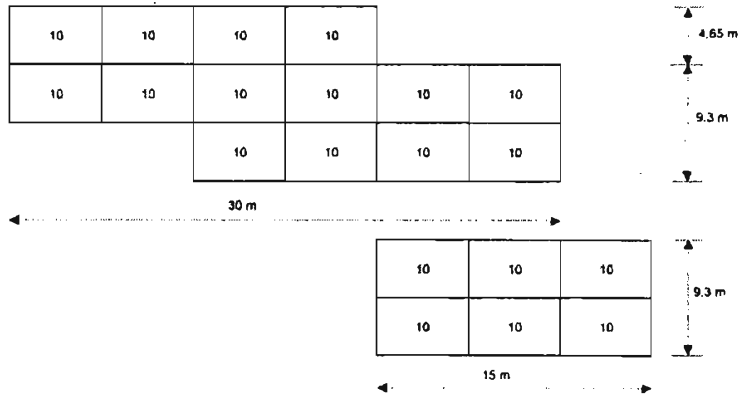

TOTAL NUMBER OF COLLECTORS $=200$ $\begin{aligned} \text { AREA COVERED BY COLLECTORS } & =400 \mathrm{sa} \cdot \mathrm{m} \\ \text { AREA UNDER STRUCTURE } & =465 \mathrm{sq} \cdot \mathrm{m}\end{aligned}$

SOLAR FIELD - PLAN VIEW

Figure 2 : Solar field-plan view.

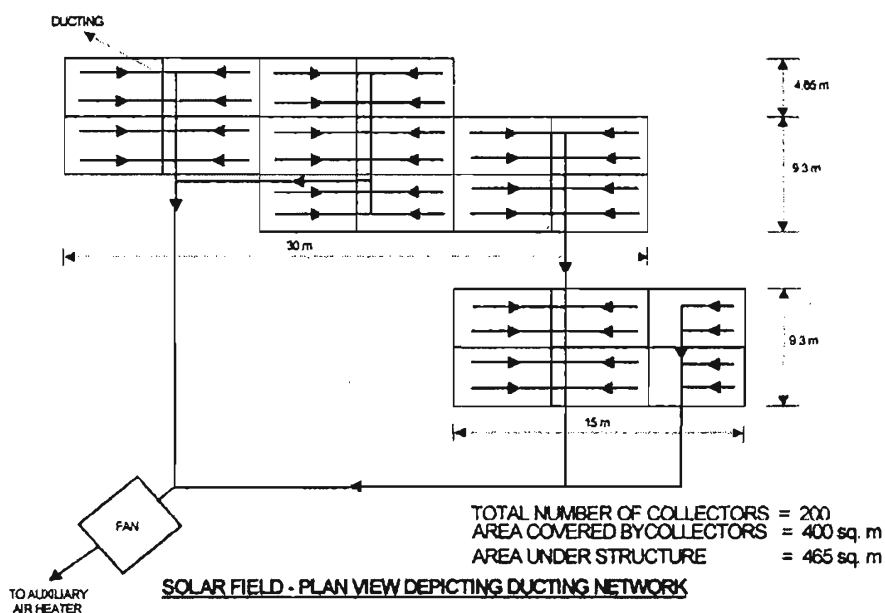

Figure 3 : Solar field-plan view depicting ducting network.

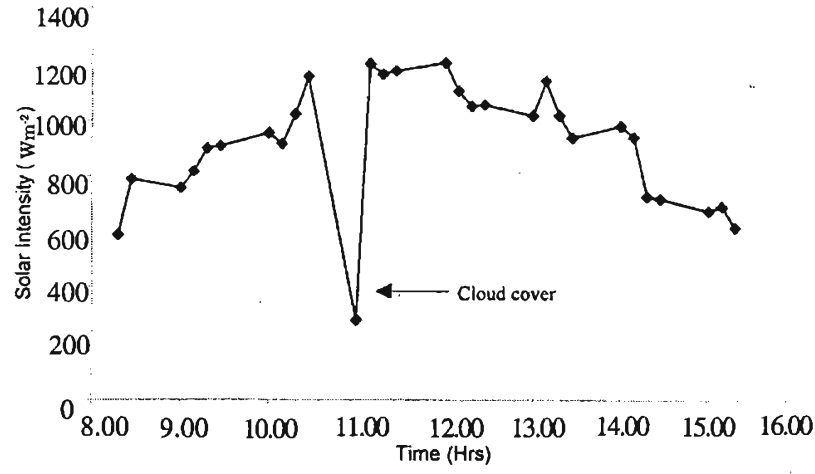

Figure 4 : Solar intensity at St.Joachim, Ratnapura. 


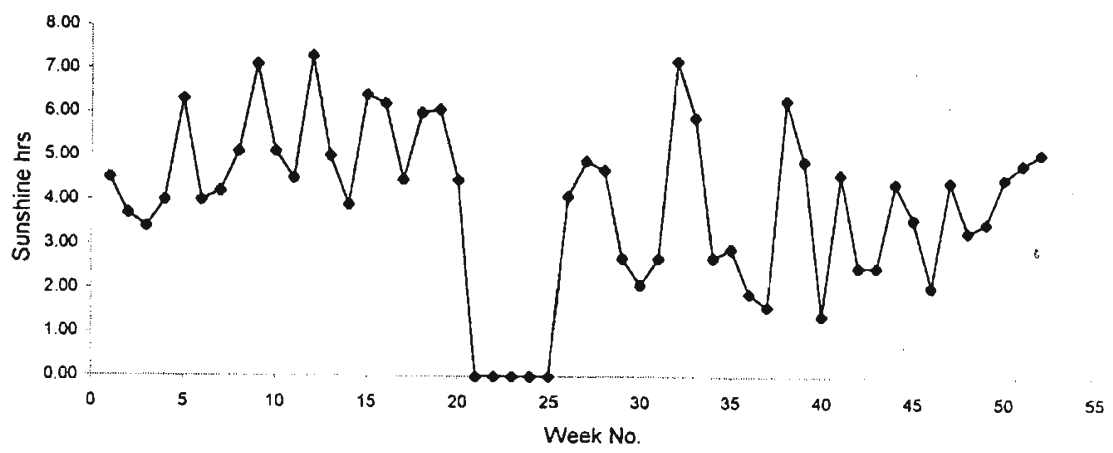

Figure 5 : Sunshine hours at St. Joachim, Ratnapura.

Table 8: Drier output and oil consumption with solar energy for preheating the air used for tea drying.

\begin{tabular}{|c|c|c|c|c|c|}
\hline$\overline{\text { Day }}$ & $\begin{array}{l}\text { Wither \% } \\
\text { (made tea } \\
\text { withered } \\
\text { leaf }^{-1} \text { ) }\end{array}$ & $\begin{array}{l}\text { Working } \\
\text { hours } \\
(\mathrm{h} / \mathrm{s})\end{array}$ & $\begin{array}{c}\text { Oil } \\
\text { consumption } \\
\text { (1) }\end{array}$ & $\begin{array}{c}\text { Oil } \\
\text { consumption } \\
\left(1 . h^{-1}\right)\end{array}$ & $\begin{array}{c}\text { Average } \\
\text { drier } \\
\text { output }(\mathrm{kg} \\
\left.\text { made tea. } \mathrm{h}^{-1}\right) \\
\end{array}$ \\
\hline 1 & 35.5 & 6.25 & 157.5 & 25.2 & 131.2 \\
\hline 2 & 38.3 & 5.33 & 121.5 & 22.7 & 134.0 \\
\hline 3 & 38.6 & 3.00 & 67.5 & 22.5 & 136.0 \\
\hline 4 & 38.0 & 5.00 & 117.0 & 23.4 & 133.3 \\
\hline 5 & 35.2 & 3.50 & 90.0 & 25.7 & 121.3 \\
\hline 6 & 37.2 & 6.00 & 144.0 & 24.0 & 126.1 \\
\hline 7 & 37.6 & 8.50 & 216.0 & 25.4 & 118.6 \\
\hline 8 & 35.4 & 2.83 & 76.5 & 27.0 & 115.4 \\
\hline 9 & 39.0 & 3.75 & 81.0 & 21.6 & 135.4 \\
\hline 10 & 38.6 & 4.00 & 90.0 & 22.5 & 129.7 \\
\hline 11 & 37.7 & 5.75 & 135.0 & 23.5 & 134.1 \\
\hline 12 & 38.1 & 7.00 & 171.0 & 24.4 & 121.3 \\
\hline 13 & 38.5 & 7.50 & 166.5 & 22.2 & 135.4 \\
\hline 14 & 38.0 & 2.00 & 45.0 & 22.5 & 135.0 \\
\hline 15 & 36.2 & 7.25 & 184.5 & 25.4 & 118.3 \\
\hline 16 & 36.1 & 2.50 & 63.0 & 25.2 & 116.7 \\
\hline
\end{tabular}


Table 9: Mean sunshine hours recorded at St. Joachim, Ratnapura.

\begin{tabular}{cc}
\hline Year & Mean sun shine hours \\
\hline 1990 & 5.6 \\
1991 & 5.3 \\
1992 & 6.8 \\
1993 & 4.8 \\
1994 & 3.9 \\
1995 & 3.8 \\
1996 & 4.3 \\
1997 & 5.1 \\
1998 & 4.4 \\
1999 & 4.0 \\
Average for 10 years & 4.8 \\
\hline
\end{tabular}

Fuel consumption by the air heater with solar field, varied between 21.6-27.0 $1 \mathrm{~h}^{-1}$, whereas it was as high as $401 \mathrm{~h}^{-1}$ without solar field. Monitoring the performance of this system, over a period of 6 months indicated a saving of about $32.5 \%$ on fuel consumption.

However, using mean sunshine hours recorded for ten years from 1990 (Table 9) a cost-benefit analysis was carried out and the results are presented in Table 10.

Table10 : Cost-benefit analysis with mean sunshine hours of 4.8 hours.

\begin{tabular}{cccc}
\hline $\begin{array}{c}\text { Saving in fuel } \\
(\%)\end{array}$ & $\begin{array}{c}\text { Pay back } \\
\text { period (Years) }\end{array}$ & $\begin{array}{c}\text { Net present value } \\
@ 15 \%(\mathrm{Rs})\end{array}$ & $\begin{array}{c}\text { Net present value } \\
@ 10 \%(\mathrm{Rs})\end{array}$ \\
\hline 30 & 4.5 & $641,046.00$ & $1,095,910.00$ \\
25 & 5.5 & $198,390.00$ & $553,959.00$ \\
20 & 6.5 & $-235,231.00$ & $23,068.00$ \\
15 & 9.5 & $-677,887.00$ & $-518,882.00$ \\
\hline
\end{tabular}

Total capital cost for installation and commissioning of the system was around Rs 2 million, which is considered to be high. This cost could be brought down by having a field with lower edge at ground level and upper edge at $1.56 \mathrm{~m}$ high from ground level at a slope of $7^{\circ}$ and also having large collectors instead of small ones used in this project. Although the efficiency of such collectors would be less compared to the collectors used in this project, it could be economically attractive. Such a system could also have a single straight ducting, which would require less capital and also minimize heat and pressure losses. 
Some grades of tea take more time to pack due to difficulties in collecting enough quantity. During this time, tea particles absorb moisture and as a result, the quality of tea degrades. To prevent the loss in quality due to moisture absorption, these grades of teas are "re-fired" before packing to maintain the moisture content within the desired levels. For such re-firing a hot air temperature of about $55-60{ }^{\circ} \mathrm{C}$ is used. Outlet temperatures above $60{ }^{\circ} \mathrm{C}$ of the pre-heated air were recorded during trials. As such, this solar system could be used for re-firing of graded teas, without an auxiliary source of energy.

The main advantages of the system are that it is renewable, environment friendly and involves minimum maintenance cost. One of the objectives of this project was to use locally available materials to fabricate the collectors. Rubberised coconut coir was used as insulation instead of glass wool and rock wool.

\section{Acknowledgement}

The authors acknowledge the financial support received from Swedish International Development Cooperation Agency (SIDA), channelled through the National Science Foundation. Valuable advises and guidance received from the Energy Committee of the National Science Foundation is also acknowledged.

\section{References}

1 Breymayer.M et al.(1993). Solar -assisted smoke house for the drying of natural rubber of small-scale Indonesian farms. Renewable Energy 3(8). Pergamon Press Ltd, New York.

2. Palaniappan C. (1993). Solar heating for tea processing: Case study. Proceedings of the First International work shop held at Coonoor, India, February 10-12.

3. Haskoning (1989). Energy consumption in the tea industry of Sri-Lanka. Royal Dutch Consulting Engineers and Architects.

4. De Silva W.C.A. (1993). Some energy saving achievements of the tea industry in Sri Lanka. Proceedings of the First International work shop held at Coonoor, India from February 10-12.

5. $\quad$ Ediriweera D.P. (1991). Electronic servo-control for withering troughs. Sri Lanka Journal of Tea Science 60(1): 30-35, TRI, Talawakelle.

6. James E. Hill (1977). Standard procedures for collector performance testing. ASHRAE, New York. 